\title{
INTERNATIONAL COOPERATION IN SPACE TECHNOLOGY：AN ABSTRACTION WITH FUZZY LOGIC ANALYSIS
}

\author{
Amit Mukherjee ${ }^{1, *}$ \\ ${ }^{1}$ National Institute of Advanced Studies (NIAS), School of Conflict and Security Studies, Bengaluru, India - \\ toamitmukherjee@gmail.com
}

Commission V, WG V/2

Keywords - Policy, Space Technology, International Space Co-operations, ISRO, Fuzzy Logic, Missions, India, Israel

\begin{abstract}
India's cooperation with International Space faring nations has a long legacy of cooperation. As India moves towards realizing its space aspirations, its co-operation for outreach and capacity building with international partners will increase. This cooperation is reflected in all spheres of national development, security and space exploration of both the primary as well as partnering nation. Policy considerations and directives acts as a key to define the future course of action for such cooperation. The paper attempts to present parameters for evaluating policy options of India's international space cooperation with an example of India-Israel space cooperation. The paper uses fuzzy logic modeling for scoring parametric valuation for pursuing cooperation. This valuation can assist in making feasibility analysis for a collaborative mission or project with a partnering nation. These parameters include the erstwhile and ongoing collaborations and cooperation, economics of the collaborative project, security considerations, technical considerations \& space ambitions. The output delivers aggregated value for 'checks and balance' derivatives for informed decision making.
\end{abstract}

\section{INTRODUCTION}

Space technology and space based data/services have become relevant for studying spatial and temporal pattern of resources in the context of burdening demand of growing populations. To enhance co-existence and better management of resources, countries are collaborating for space technology, space infrastructure sharing, space data distribution and utilization for societal benefits. 'Space' forms a trans-national dimension for international cooperation and goodwill generation. International collaborations in space technologies are focused on scientific and technological factors along with political, economic and cultural aspects, which eventually lead to strategic long standing partnership or relation. Though literature exists about the cooperation and policies describing how successful they have been, very few indicate any logical quantification in this regard. This paper identifies inter-relationship of prominent Indian space collaborations with International communities along with their respective components and their relevance (section-2). An attempt is made to indicate a logical qualitative analysis (in section-3) onwards assessing suitability of International space cooperation with an example.

\section{SPACE TECHNOLOGY CO-OPERATION FOR INDIA}

Space program of a country is amicably interlinked with three factors - i) Science \& engineering, ii) Commerce and iii) Security. Establishment of a long term space science/ engineering and $\exp ^{1}$ loration efforts are primarily discouraged by high cost of space technology programs and nurturing of competent human resources that needs to be built over a substantial period of time. International co-operation in space technology is rewarding for a set of nations to achieve common space science objectives in the following areas-

- Stronger space research program leading to the development of specialized technological capability.
- Transfer of Technology in energizing sectors/ application, which otherwise would have taken several years to develop.

- Use of common space-infrastructures and sharing of space based data for resource management and societal benefits.

- National security agreement towards space security among the nations.

- Enhanced research in science, technology, engineering with more number of students / professionals and its impact on education and economy.

- Better understanding of planetary exploration science and technology for information and evaluation of universe (impacts on Astro-Physics)

The prominent space faring nations are USA, Russia, Europe, France, Japan, China, Canada, UK and India. Up until a decade back India was the only developing nation developing space technology. More nations have joined this group in the last decade. In early years of the $21^{\text {st }}$ century, policy emphasis lead towards conception of thematic satellites for geophysical products as well thematic data sharing in collaborative mode between nations. Space data sharing policy, product generation and sharing, quality measurement methods etc evolved with increasing international sharing of data and technology. In this regard leading role is played by NASA, ESA, CNES, JAXA, ISRO and other international space forums. On the other hand, technological viability for smaller and cheaper alternatives with micro / nano / pico satellites made space technology more affordable in recent times. Several MOUs have been signed between different nations for development of satellites; launch services and data products sharing. The world is moving towards a new era of multi-level and multi-dimensional space based management.

\footnotetext{
* Corresponding Author
} 


\subsection{Collaboration in Space and Ground Segment}

India has adopted a strong passion towards development of space technology and missions. It has international cooperation components in many of its missions from the launch of Rohini and Aryabhatta in the early days to the recent Chandrayan-I and Mangalyan mission (https://www.isro.gov.in/launchers/list-ofpslv-launches). The major component of space cooperation between ISRO and international community are in the fields of -

- Launch vehicle and launch service.

- Payloads and sensors - scientific and civilian mission.

- Space communications and infrastructure.

- Tracking and data reception facilities.

ISRO has formal agreements / MOUs with many nations and organizations, namely include Argentina, Australia, Brazil, Brunei, Darussalam, Bulgaria, Canada, Chile, Egypt, European Center for Medium Range Weather Forecasts, European Organization for the exploitation of Meteorological Satellites, EUMETASAT, European Space Agency, France, Germany, Spain, Sweden, Syria, Thailand, Netherlands, Ukraine, UK, USA and Venezuela. This proves the growing worthiness and benefits of International space cooperation (unoosa.org 2018) as a practice and policy. Major international space collaborations between India along with respective components are compiled from open source information (table 1).

\begin{tabular}{|c|c|c|c|}
\hline Element & Components & Mission & Country \\
\hline $\begin{array}{l}\text { Lift } \\
\text { vehicle }\end{array}$ & Launch & Aryabhatta \& Rohini & $\begin{array}{l}\text { Russia, } \\
\text { USA }\end{array}$ \\
\hline \multirow[t]{2}{*}{$\begin{array}{l}\text { Heavy } \\
\text { launch } \\
\text { vehicle }\end{array}$} & \multirow[t]{2}{*}{$\begin{array}{l}\text { Lift vehicle } \\
\text { and launch } \\
\text { service }\end{array}$} & $\begin{array}{l}\text { Ariane for } 18 \\
\text { Geostationary } \\
\text { satellite }\end{array}$ & France \\
\hline & & $\begin{array}{l}\text { GSLV, GSAT for } \\
\text { GLONASS }\end{array}$ & India \\
\hline \multirow{10}{*}{$\begin{array}{l}\text { Light } \\
\text { launch } \\
\text { vehicle }\end{array}$} & \multirow{9}{*}{$\begin{array}{l}\text { Lift vehicle } \\
\text { and launch } \\
\text { service (PSLV) }\end{array}$} & SPOT 6,7 & India \\
\hline & & TECSAR & India \\
\hline & & Small satellites & $\begin{array}{l}\text { Europe } \\
\text { (Astriam) }\end{array}$ \\
\hline & & Megha Tropiques & France \\
\hline & & Saral Altika & France \\
\hline & & Cubesat & Taiwan \\
\hline & & NISAR & India \\
\hline & & YouthSat & Russia \\
\hline & & $\begin{array}{l}\text { Nanosatellite } \\
\text { constellation } \\
\text { AISSAT } 1 \text { \& } 2\end{array}$ & Norway \\
\hline & $\begin{array}{l}\text { GSAT } 9 \text { and } \\
\text { launch service }\end{array}$ & South Asian Satellite & India \\
\hline Engine & $\begin{array}{l}\text { Liquid engine } \\
\text { technology in } \\
\text { PSLV Second } \\
\text { stage }\end{array}$ & PSLV & France \\
\hline
\end{tabular}

\begin{tabular}{|l|l|l|l|}
\hline Engine & $\begin{array}{l}\text { KVD-1 } \\
\text { Cryogenic } \\
\text { engine }\end{array}$ & GSLV upper stage & Russia \\
\cline { 2 - 3 } & $\begin{array}{l}\text { Electric ion } \\
\text { propulsion } \\
\text { engine (EIP) }\end{array}$ & $\begin{array}{l}\text { South Asian Satellite } \\
\text { for } \\
\text { countries }\end{array}$ & Japan \\
\hline
\end{tabular}

Table-1. Collaboration for components for Launch vehicles and Launch Services.

Green color indicate that India is providing service and blue color indicate that India receives service / technology from international community, yellow color indicates joint development. Pink color indicates short term and lavender color indicates medium to long term cooperation.

\begin{tabular}{|c|c|c|c|}
\hline Element & Components & Mission & Country \\
\hline \multirow[t]{8}{*}{ Sensors } & $\begin{array}{l}\text { SAPHIR and } \\
\text { SCARAB }\end{array}$ & \multirow[t]{2}{*}{$\begin{array}{l}\text { Megha } \\
\text { Tropiques }\end{array}$} & France \\
\hline & MADRAS & & $\begin{array}{l}\text { France \& } \\
\text { India }\end{array}$ \\
\hline & $\begin{array}{l}\text { ALTIKA, ARGOS, on } \\
\text { board radiometer }\end{array}$ & SARAL & $\begin{array}{l}\text { France \& } \\
\text { India }\end{array}$ \\
\hline & $\begin{array}{l}\mathrm{L} \text { band (NASA), S } \\
\text { band (INDIA) }\end{array}$ & NISAR & $\begin{array}{l}\text { USA \& } \\
\text { India }\end{array}$ \\
\hline & $\begin{array}{l}\text { X Ray astronomy } \\
\text { mission }\end{array}$ & $\begin{array}{l}\text { Coronas } \\
\text { Photon }\end{array}$ & Russia \\
\hline & ROSA & Oceansat-2 & Italy \\
\hline & ARGOS & Oceansat-3 & France \\
\hline & $\begin{array}{l}\text { Meteorological sensor, } \\
\text { Transponder, data } \\
\text { reception }\end{array}$ & $\begin{array}{l}\text { South } \\
\text { Asian } \\
\text { satellite }\end{array}$ & India \\
\hline \multirow[t]{5}{*}{$\begin{array}{l}\text { Science } \\
\text { Payload }\end{array}$} & $\begin{array}{l}\text { Spectrometer, SIR-2, } \\
\text { SARA, Radome, } \\
\text { MiniSAR, Moon } \\
\text { mineralogy mapper }\end{array}$ & $\begin{array}{l}\text { Chandraya } \\
\text { an-1 } \\
\text { X-ray. }\end{array}$ & $\begin{array}{l}\text { ESA(UK, } \\
\text { Germany, } \\
\text { Sweden, } \\
\text { Bulgaria,) } \\
\text { USA }\end{array}$ \\
\hline & Deep Space Network & Mangalyan & USA \\
\hline & $\begin{array}{l}\text { Ultraviolet imaging } \\
\text { telescope }\end{array}$ & Astrosat & Canada \\
\hline & $\begin{array}{l}\text { X-ray astronomy } \\
\text { Instrument }\end{array}$ & $\begin{array}{l}\text { Coronas } \\
\text { Photon }\end{array}$ & India \\
\hline & $\begin{array}{l}\text { Space } X \text { ray } \\
\text { observation }\end{array}$ & $\begin{array}{l}\text { X ray } \\
\text { instrument }\end{array}$ & Japan \\
\hline
\end{tabular}

Table 2. Collaborations for development / contributions of Payload / Sensors

Most common International cooperation happens in the form of MOU in telemetry and tracking where restricted ground access in other countries becomes accessible for tracking (Table-3). 


\begin{tabular}{|c|c|c|c|}
\hline Element & Components & Mission & Country \\
\hline \multirow[t]{4}{*}{$\begin{array}{l}\text { Telemetry } \\
\& \text { tracking }\end{array}$} & $\begin{array}{l}\text { Deep space } \\
\text { network for } \\
\text { MOM launch } \\
\text { monitoring }\end{array}$ & Mars Mission- & USA \\
\hline & $\begin{array}{l}\text { Ground station, } \\
\text { Antenna }\end{array}$ & Chandrayaan-1 & Russia \\
\hline & $\begin{array}{l}\text { Ground station } \\
\& \text { data reception }\end{array}$ & $\begin{array}{l}\text { Different } \\
\text { missions of } \\
\text { India }\end{array}$ & $\begin{array}{l}\text { Brunei, } \\
\text { Indonesi } \\
\text { a }\end{array}$ \\
\hline & $\begin{array}{l}\text { Ground station } \\
\& \text { antenna }\end{array}$ & $\begin{array}{l}\text { GLONASS } \\
\text { Ground station }\end{array}$ & $\begin{array}{l}\text { Russia \& } \\
\text { India }\end{array}$ \\
\hline $\begin{array}{l}\text { Satellite } \\
\text { communicati } \\
\text { on }\end{array}$ & $\begin{array}{l}\text { Satellite } \\
\text { telecommunicati } \\
\text { on experiment }\end{array}$ & $\begin{array}{l}\text { Tech. Transfer } \\
\text { to develop own } \\
\text { communicatio } \\
\mathrm{n} \text { satellite }\end{array}$ & Germany \\
\hline $\begin{array}{l}\text { Space based } \\
\text { power } \\
\text { exchange }\end{array}$ & \begin{tabular}{l} 
Ground station\} $\\
{\text { antenna }}$ & Demonstration & USA \\
\hline Navigation & & GLONASS & India \\
\hline $\begin{array}{l}\text { Human } \\
\text { Space Flight }\end{array}$ & $\begin{array}{l}\text { Flight for } \\
\text { Cosmonaut } \\
\text { onboard }\end{array}$ & Salyut-7 & Russia \\
\hline
\end{tabular}
\end{tabular}

Table-3 Cooperation in ground segment and other areas

\subsection{Space Data sharing with International Communities}

- India is playing a leading role in Sentinel Asia initiative under International disaster charter operations to support disaster management in the Asia-Pacific region applying remote sensing and Web-GIS technologies.

- Megha-Trophiques processed data from ROSA and SAPHIR sensor are shared with international users for study of the tropical atmosphere / climatic conditions.

- Astrosat SARAL (ALTIKA and ARGOS) data is shared with international community for studying ocean from space altimetry.

- Information generated using Oceansat-2 and Scatterometer is made available globally in near-real time for global applications through an arrangement with Eumetsat.

- ISRO is in cooperation with USGS for Landsat $7 \backslash 8$ and Resourcesat-2 data sharing, with NASA for Scatsat $\backslash$ Rapidsat data utilization $\backslash$ and with ESA for IRS, Sentinel data sharing, and with Canada for microwave data sharing (eeas.europa.eu).

- Antrix and NRSC signed MOUs with different international space agencies for receiving their satellite data using Indian ground station and providing Indian satellite data to International community.

- Antrix is in collaboration to sell IRS, CARTOSAT, data in Australia and African countries.

Such cooperation is paving the way for experimenting with new sensors and working jointly. India has launched more than 50 satellites for more than 20 different nations by 2018, including African \& Asian countries and developed countries (USA, France, Canada and Europe). The share ISRO's income generated from commercial satellite launch towards Indian economy has increased significantly.

\subsection{Space Utilization - India's involvement}

India is in active cooperation with space forum of other countries like GEOS, ATRFAS, UN-ESCAT etc. for natural resource management and monitoring, disaster management and capacity building. Under UN-ESCAP program, India is providing technical support for development of Draught monitoring system using satellite data with field data collection and data viewing at Bhuvan through an exclusive access. ISRO also provide training and hand holding for data processing and analysis.India and EU have a established cooperation for space research and technology. This India-EU space cooperation has multitude of facets that have been agreed upon (esa.int). These include space security, space situational awareness, multi object tracking radar etc.

\subsection{Collaboration in Capacity Building}

Indian cooperation with international and regional countries is strongly linked with capacity building. Institute of Remote Sensing (IIRS) and UN affiliated Centre for Space Science and Technology Education in Asia and Pacific (CSSTEAP) involves in capacity building of 55 countries of east, south-east Asia, central Asia, Pacific. It offers short term training courses and 9 months and PG diploma on space technology application about remote sensing and GIS, SATCOM, SATMET, Space Science and GNSS. IIRS also offers 8 weeks course on RS and GIS under Indian Technical Economic Cooperation (ITEC) sponsored by MEA. More than 1600 officials from 93 countries are offered training by IIRS and CSSTEAP (http://www.cssteap.org/). To assess the impact of International Space cooperation on overall education / research of science and engineering at India, relevant data is not available (scholarly citation impact is negligible). The joint Civil Space Working group (between USA and India) discussed India's participation in NASA led GLOBE education program (Global Learning and Observations to Benefit the Environment). However, the number of enrollments of schools in India is less encouraging. In all the above mentioned areas of cooperation, the relevant policy documents plays a very important role in defining the course of action and its future success, which needs to be assessed.

\section{MODELING INTERNATIONAL SPACE COOPERATION WITH FUZZY LOGIC.}

Policy on international space cooperation can be accessed through measuring the mix of uncertainties that enables, hastens, prolongs, delays or causes failure of international space cooperation. At present international space co-operations are judged by mode of operation between participating countries, transaction cost to achieve mission elements or technology, and analyzing past instances of interaction / cooperation between participating countries. Most of the time a technological component as well as high development cost is involved with space co-operation. This factor triggers the requirement of the techno-political analysis of space cooperation for a better understanding of the interplay of parameters. Policy imperatives for domestic and global influence in the arena of international space cooperation can be modeled. The cooperation in terms of economic benefit, influencing regional and global strategic interests, enhancing national prestige, domestic economic well being can be measured through such modeling. This paper develops a Fuzzy Logic model for understanding international cooperation on space technology and its indication towards achieving success using these parameters (Fig. 1). 


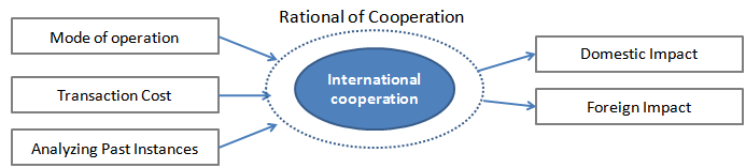

Fig. 1. Block Diagram of International Space cooperation

\subsection{India-Israel cooperation framework: An Example}

There are two types of partners in any cooperation model. 'Primary' nation initiates / seeks the cooperation and the 'Partner' nation provides technology, mission element or services. India-Israel cooperation for RISAT (Blarel et all) mission has been studied with the generally acknowledged and accepted notions of benefit to both nations in the context of this model. India is considered as the 'Primary nation' and Israel is the 'Partner nation'. Underlying assumptions about India and Israel (table-4) need to get translated into a calculable matrix of parameters.

\begin{tabular}{|c|c|}
\hline India & ssrael \\
\hline 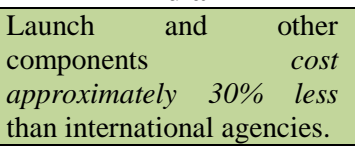 & $\begin{array}{l}\text { Space technology components } \\
\text { costs much higher than India } \\
\text { most of the time. }\end{array}$ \\
\hline $\begin{array}{l}\text { Indigenous development in } \\
\text { launch vehicle, space port } \\
\text { and other infrastructure / } \\
\text { asset base }\end{array}$ & $\begin{array}{l}\text { Indigenous development in } \\
\text { advanced optical, SAR sensors } \\
\text { and techniques, }\end{array}$ \\
\hline $\begin{array}{l}\text { Leader in launching LEO } \\
\text { satellites, providing remote } \\
\text { sensing data in civilian } \\
\text { applications. }\end{array}$ & $\begin{array}{l}\text { Leader in defence satellites with } \\
\text { advanced sensors, expertise in } \\
\text { miniaturization of hardware } \\
\text { component for mission, U AV }\end{array}$ \\
\hline $\begin{array}{l}\text { Aiming at becoming a } \\
\text { major space power with } \\
\text { increased market share for } \\
\text { space launch. }\end{array}$ & $\begin{array}{l}\text { Aiming at increased market share } \\
\text { for sensor technology and } \\
\text { Mission hardware }\end{array}$ \\
\hline $\begin{array}{l}\text { Primary focus area is } \\
\text { development and benefit of } \\
\text { the society }\end{array}$ & $\begin{array}{l}\text { Primary focus area is defence and } \\
\text { national security. }\end{array}$ \\
\hline $\begin{array}{l}\text { Launched Israeli Satellite } \\
\text { TECSAR in } 2007\end{array}$ & $\begin{array}{l}\text { Sensor contribution for Indian } \\
\text { satellite RISAT. }\end{array}$ \\
\hline $\begin{array}{l}\text { Inter planetary missions } \\
\text { (Moon and Mars mission) } \\
\text { achieved with lower cost, } \\
\text { indicating technology } \\
\text { demonstration and } \\
\text { enhanced national pride. }\end{array}$ & $\begin{array}{l}\text { Scope of future cooperation in } \\
\text { interplanetary joint mission by } \\
\text { developing sensors like ultra- } \\
\text { violet, x-ray imaging instrument } \\
\text { and other sensors suitable for } \\
\text { astrophysics application. }\end{array}$ \\
\hline $\begin{array}{l}\text { Indian manufacturing can } \\
\text { reduce the cost of satellite } \\
\text { systems }\end{array}$ & $\begin{array}{l}\text { Extended } \mathrm{R} \& \mathrm{D} \text { can gain pace } \\
\text { with collaboration due to limited } \\
\text { budgets. }\end{array}$ \\
\hline \multicolumn{2}{|c|}{$\begin{array}{l}\text { Invested funds for joint industrial development, including in } \\
\text { space technology. }\end{array}$} \\
\hline \multicolumn{2}{|c|}{$\begin{array}{l}\text { Both the countries can increase their market share by combining } \\
\text { the strength and expertise in launch vehicle, launch service } \\
\text { (India) and advanced sensors (Israel). }\end{array}$} \\
\hline
\end{tabular}

Table 4. Facts \& Assumptions for India Israel Cooperation.

Green - Cost related parameters, Pink - Policy parameters, Blue - Technical efficiency/capability related parameters, LavenderCombination of more than one parameter, Yellow- Scope for joint development.

\subsection{Fuzzy logic design and modeling:}

An attempt has been made to model such complex scenario and interwoven parameters with Fuzzy Logic to get a better understanding of policy. The parameters considered are in synchronization with the assumptions mentioned at table 4 , which were felt important by the subject expert on policy.
It has been applied to test the feasibility of collaboration between India and Israel. Modeling has been created using Fuzzy Logic in Matlab.

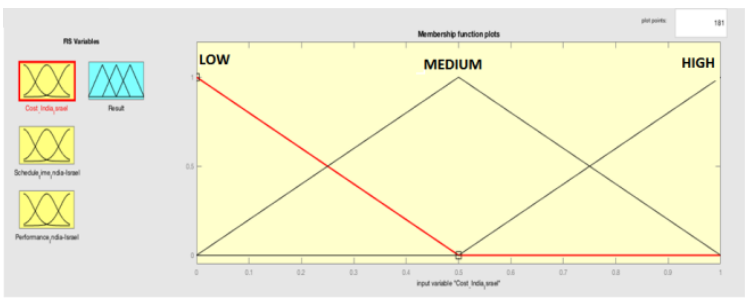

Figure 2 Fuzzy Concept \& Membership Function

Fuzzy models convert crisp values into fuzzy values to provide an indication of variables that cannot give discrete output. It is helpful in qualitative assessment of variables that answer queries on subjective nature of assessments. The collaboration scenario is captured through technical, cooperative and policy related parameters that influence the deal (Juan Miguel et all ).

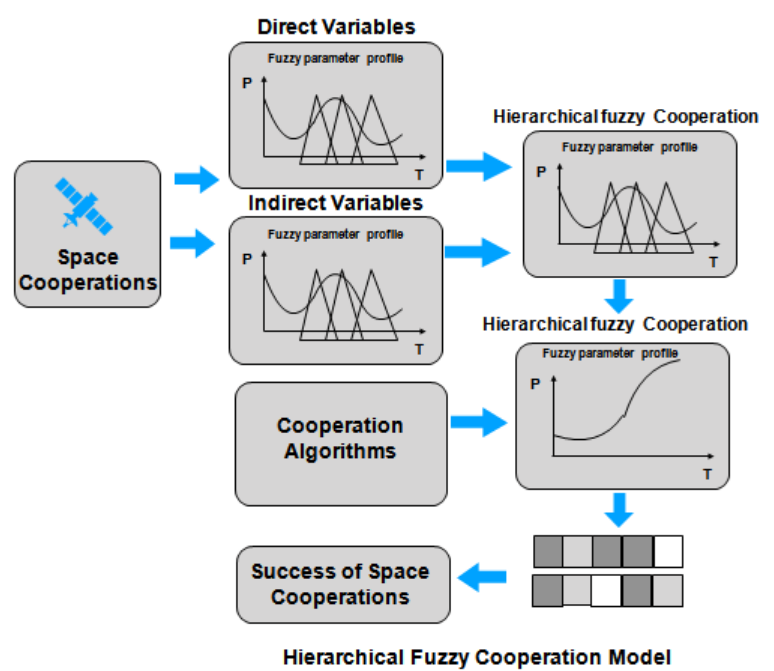

Fig.-3 Flow chart of Fuzzy Model implemented for assessment of space cooperation.

Some of the variables are direct parameter which directly affect the quality of the cooperation (example: Cost). Few of them are derived parameters using more than one parameter, statistically or by expert opinion. A parameter sometimes acts as a control variable indicating its overriding powers on other parameters (political willingness, national security etc). The condition that defines the relationship is based on the type of variables and their inter-relationship.

\subsection{Parameters defining collaboration policy}

The parameters indicating success in space cooperation are mainly categorized as-

- Technical Parameters, through assessment of cost, schedule/ time, performance/efficiency, safety, risk.

- Policy Parameters includes national pride, security, regional influence, domestic economy, maintain technicality,

- Cooperative Parameters is constituted by indicating long term or short term collaboration.

In this example understanding favorable conditions for joint missions, where advanced sensors and data processing services 
provided by Israel, has been enlisted. Launch vehicle, launch services along with other infrastructures are provided by India.

\begin{tabular}{|c|c|c|}
\hline $\begin{array}{l}\text { SL } \\
\text { no }\end{array}$ & Parameter & Indication / Meaning \\
\hline \multicolumn{3}{|c|}{ Technical Parameter } \\
\hline 1 & $\begin{array}{l}\text { Cost } \\
\text { effectiveness }\end{array}$ & $\begin{array}{l}\text { Incurred by each partnering nation } \\
\text { for proposed mission }\end{array}$ \\
\hline 2 & $\begin{array}{l}\text { Time frame } \\
\text { and schedule }\end{array}$ & $\begin{array}{l}\text { shortest time for receiving mission } \\
\text { component/technology } \\
\text { completion of a joint project }\end{array}$ \\
\hline 3 & $\begin{array}{l}\text { Performance } \\
\& \quad \text { Technical } \\
\text { Capability }\end{array}$ & $\begin{array}{l}\text { Effectiveness of mission elements } \\
\text { or project. }\end{array}$ \\
\hline \multicolumn{3}{|c|}{ Cooperation Parameters } \\
\hline 4. & $\begin{array}{l}\text { Short Term } \\
\text { Acquisition }\end{array}$ & $\begin{array}{l}\text { Purchase of component that has } \\
\text { limited life span }\end{array}$ \\
\hline 5. & $\begin{array}{l}\text { Long Term } \\
\text { Acquisitions }\end{array}$ & $\begin{array}{l}\text { Purchase of components that have } \\
\text { long service life }\end{array}$ \\
\hline 6. & $\begin{array}{l}\text { Collaborations } \\
\text { with other } \\
\text { nations }\end{array}$ & $\begin{array}{l}\text { These are collaborative projects that } \\
\text { have taken place or can take place } \\
\text { based on efficacy of favoring } \\
\text { conditions }\end{array}$ \\
\hline \multicolumn{3}{|c|}{ Policy Parameters } \\
\hline 7. & $\begin{array}{l}\text { Economic } \\
\text { Capability }\end{array}$ & $\begin{array}{l}\text { The economic capability of a nation } \\
\text { to take space related developmental } \\
\text { activities }\end{array}$ \\
\hline 8. & $\begin{array}{l}\text { Technical } \\
\text { Capability }\end{array}$ & $\begin{array}{l}\text { Technical capability of partnering } \\
\text { nation to take an endeavor for space } \\
\text { missions }\end{array}$ \\
\hline 9. & $\begin{array}{l}\text { Domestic and } \\
\text { international } \\
\text { influence }\end{array}$ & $\begin{array}{l}\text { of policy makers to make case for } \\
\text { such international space } \\
\text { cooperation that is entwined with } \\
\text { the elements of national pride and } \\
\text { national security }\end{array}$ \\
\hline
\end{tabular}

Table 5. Summarizes the parameters with their indicative meaning

A Fuzzy cognitive map in Fig. 4 is depicting the interrelationship of different parameters/ variable with positive and negative indicators. Red Line indicates negative relation between affected and causal variables; Blue Line indicates positive relationship between affected and causal variables.

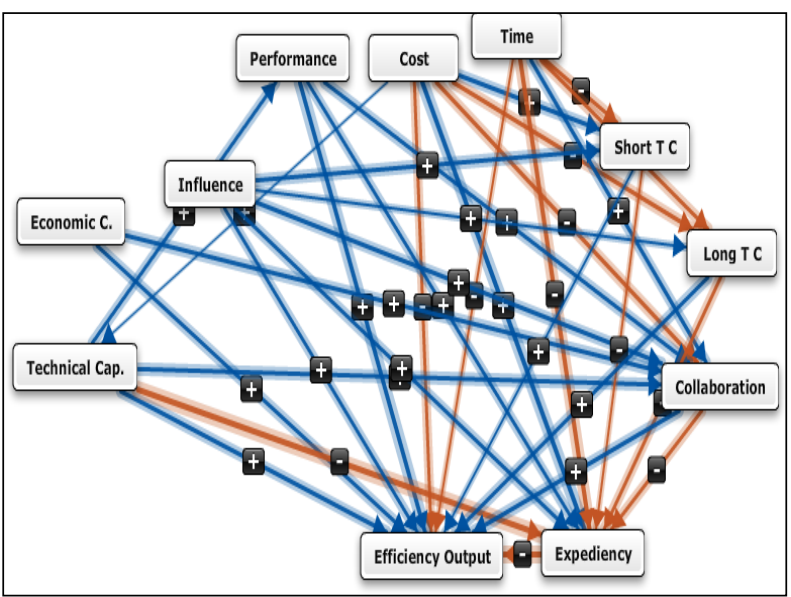

Figure 4: Cognition Model of Inter-relationship of parameters

A fuzzy set is defined by a value that varies between 0 (lowest or false) and 1 (highest or true), which assigns the membership function to each element in the set (Wang et all). The shape of the membership function can be linear (triangular or trapezoidal) or non-linear (Gaussian, Sigmoidal, Generalised Bell, Gama etc) depending on the nature of the system. To implement these functions an expert's opinion is associated in the form weighted values to the variables in the set. Performance indicators (Table 5) of a space cooperation policy are associated with indicated membership function. Weighted gradations of different parameters (Table $6 \&$ 7) were made while keeping in mind the assumptions as per table 4.

\begin{tabular}{|l|l|l|l|}
\hline $\begin{array}{l}\text { Measure } \\
\text { Index }\end{array}$ & $\begin{array}{l}\text { Range of } \\
\text { variables }\end{array}$ & Values & Categories \\
\hline Very Low & $0-20$ & Less & B \\
\hline Low & $20-40$ & Good & B+ \\
\hline Moderate & $40-60$ & Good & A \\
\hline High & $60-80$ & Very Good & A+ \\
\hline Very High & $80-100$ & Excellent & A++ \\
\hline
\end{tabular}

Table 6 Weightage of parameters (Source Arias et al, 2011)

The weighted values are then graded according to range to quality sections like B, B+, A, A+, A++.

\begin{tabular}{|l|l|l|l|l|l|}
\hline & & \multicolumn{4}{|c|}{ Grade - partner nation } \\
\hline & & Less & Good & $\begin{array}{l}\text { Very } \\
\text { Good }\end{array}$ & Excellent \\
\hline \multirow{2}{*}{$\begin{array}{l}\text { Grade } \\
-\end{array}$} & Less & B & A & A & A \\
\cline { 2 - 7 } nost & Good & B + & A & A+ & A+ \\
\cline { 2 - 7 } & $\begin{array}{l}\text { Very } \\
\text { good }\end{array}$ & A & A+ & A+ & A++ \\
\cline { 2 - 7 } & Excellent & A+ & A+ & A++ & A++ \\
\hline
\end{tabular}

Table 7 Gradation of Parameters

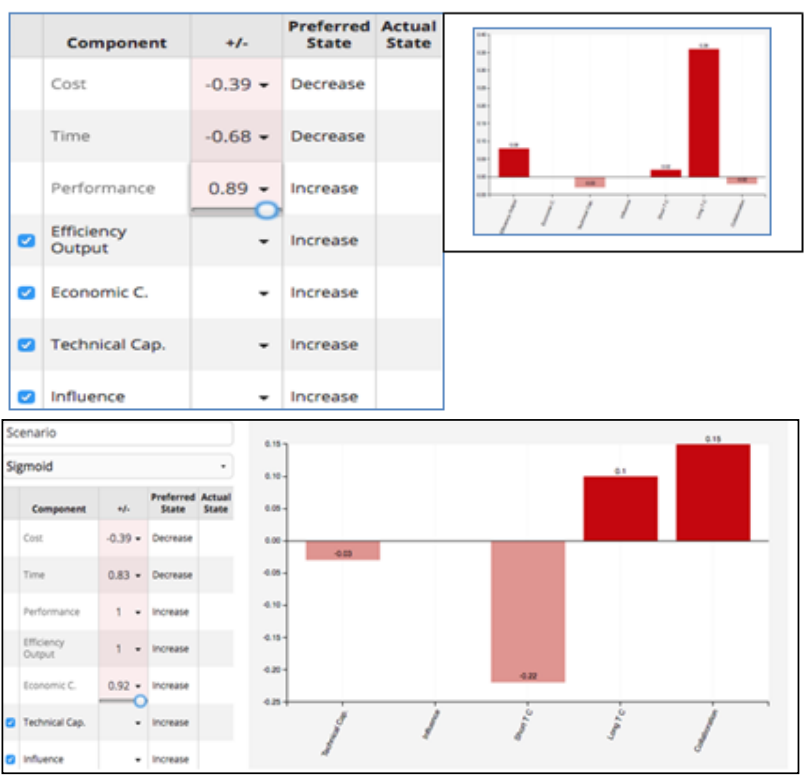

Fig 5a, 5b. Fuzzy Cognition Matrix

Fuzzy Cognition Mapping Matrix (Fig 5a), shows that if 'cost' and 'performance' measures are ideal (value $<=0.5$ ), involvement for longer 'time' becomes best suited for long term acquisitions. If 'economic' capability and 'efficiency' is high, chances of 'collaboration' (instead of mere acquisitions) (5b) increases substantially.

\subsection{Fuzzy rule-sets and output}

Relations between parameters can be defined using Fuzzy inference rules. Mamdani Min-Max approach is adopted here to 
infer the degree of membership (Wang 2015 et all). Examples of rules are -

\author{
Using IF-THEN-ELSE Rules \\ IF input Cost_Variable is Less AND \\ Time Variable is Less AND \\ Performance_value is More THEN \\ Result Output is (Defuzzification) High .

\section{IF Cost_Variable is More AND \\ Time_Variable is Less AND \\ Performance_value is LESS THEN} \\ Result Output is (Defuzzification) Medium. \\ IF Cost_Variable is More AND \\ Time_Variable is More AND \\ Performance_value is LESS THEN \\ Result is (Defuzzification) Low .
}

Implementing the rules through Fuzzy Models we can test and derive at the high output values for different inputs. Cost-TimePerformance output indicates the inter-relation of Cost, Time and Performance (Fig.6). If the cost is on higher side, the output value reduces $(17.6 \%)$ from the current indicated value $(75.5 \%)$. The best combination is when the lowest projected per-partner costs, time scale values are lower and the performance value is on the higher side (Fig 6).

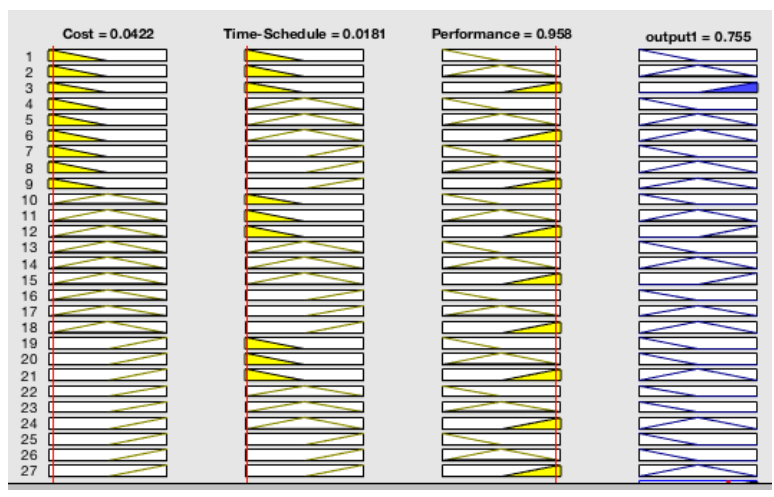

Figure 6. Cost-Time-Performance Fuzzy Model (red line moving towards right side indicates higher value)

In the case of acquiring RISAT satellite, cost value was high, time was low and performance is on the higher side. Though it is far from ideal condition (low cost, time and high performance), India's procurement with security considerations overruled other factors. Such decision is often subject to policy and political or security considerations and are not always based on ideal case (Fig 5).Similar concept is implemented for deriving the output of Policy and Cooperative parameters using weighted values in fuzzy model. The outputs of Technical, policy and Cooperative models are used to derive final output in this hierarchical fuzzy model for assessing ideal condition for India Israel cooperation (Fig 6).

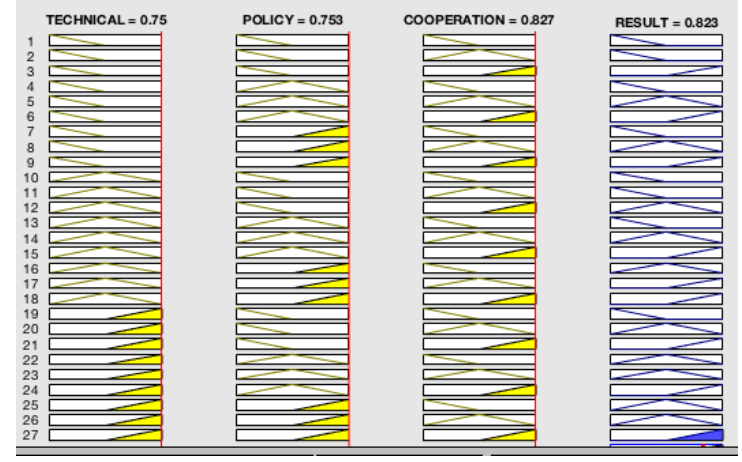

Fig. 7 Cooperation Success Index - Fuzzy Model

Resultant values indicate (Fig 6) higher chance of success if all parameters show positive trends. The India-Israel model showed an output value of $(82.3 \%)$ success rate. This puts the grade of cooperation at A++ (Table $6 \& 7)$.

If cooperation policy is not very active then cooperation success index is low. This implies that other than technical imperatives and cooperation history a policy orientation becomes the primary requirement for achieving higher results in India-Israel cooperation. Technical capabilities, regional domestic and global influence is appropriate for both India and Israel for space cooperation in strategic and security dimensions.

\section{CONCLUSION}

Fuzzy modeling for assessing space cooperation is a novel approach, which has the potential to assess different interplaying parameters individually and as a whole for higher and effective decision making policy. As per the output model the success of India Israel cooperation increases the chances of success if policy implementation supports the individual parameters. For India-Israel space cooperation parameters related to policy plays a crucial role and sometimes acts as a control variable. It may be inferred that the cost of production and research can be brought down by collaborative project between both the nations by contributing in respective areas of expertise. This model has a potential to be implemented for other areas of space cooperation with various nations to understand the inherent strength and weakness.

\section{ACKNOWLEDGMENT}

The author is thankful to Dr Rajaram Nagappa, Head of the Department, International Strategic \& Security Studies Program, School of Conflict and Security Studies, at National Institute of Advanced Studies for his guidance and support. 


\section{REFERENCES}

Abhyankar Rajender, 2009. In: The Evolution and Future of India-Israel Relations, Aspen Institute India, The Harold Hartog School of Government and Policy.

Adigun Ade Abiodun, 2002. In: An International Remote Sensing System: A Possibility, Office for Outer Space Affairs, United Nations, New York, N.Y. 10017. http://www.isprs.org/proceedings/xxix/congress/part1/25_XXI X-part1.pdf

Blarel Nicholas, 2015, The Evolution of India's Israel policy: continuity, Change and Compromise since 1922. Routledge

Chonghua Wang, 2015, A Study of Membership Functions on MamdaniType Fuzzy Inference System for Industrial DecisionMaking. Lehigh University Lehigh Preserve. https://preserve.lehigh.edu/cgi/viewcontent.cgi?article=2665\&c ontext=etd

Claudio Cioff-Revillam, 1981. In: Fuzzy Sets and Models of International Relations, American Journal of Political Science, George Mason University, Vol.- 25, No 1, pp 129-159. https://papers.ssrn.com/sol3/papers.cfm?abstract_id=2214342

Coren Ora, Tiny Satellite to Play Major Role in Israel's Space Ambitions Three nanosatellites due to be launched in next 18 months will help find break signals of people who are missing or in distress. 2015

http://www.haaretz.com/israel-news/science/.premium1.637796

European Commission and Department of Space of India signed historic Cooperation Arrangement to share satellite Earth Observation data, 2018.

https://eeas.europa.eu/delegations/india/41583/europeancommission-and-department-space-india-signed-historiccooperation-arrangement-share_en

Haretz, Israeli Lunar Project Launches Crowd-funding Campaign, - 2014.

http://www.haaretz.com/israel-news/1.590629

https://www.esa.int/Our_Activities/Space_Science/India_Europ e_cooperation

India's Reusable Launch Vehicle-Technology Demonstrator (RLV-TD), Successfully Flight Tested -2016.

http://www.isro.gov.in/update/23-may-2016/india's-reusablelaunch-vehicle-technology-demonstrator-rlv-td-successfully

India-France Joint Vision for Space Cooperation, New Delhi, 2018. http://mea.gov.in/bilateral-

documents.htm?dtl/29597/IndiaFrance+Joint+Vision+for+Spac e+Cooperation+New+Delhi+10+March+2018

International Cooperation,

https://www.isro.gov.in/international-cooperation

J. Wright Dawn, Duncan Sally L. and Lach Denise, Social Power and GIS Technology, 2009. In: A Review and Assessment of Approaches for Natural, Source: Annals of the Association of American Geographers, Vol. 99, No. 2. https://www.tandfonline.com/doi/abs/10.1080/00045600802686 299

Lootsma A Freerk, 1997 In: Fuzzy Logic for Planning and Decision Making, Applied Optimisation, Deft University of technology, Volume 8. http://marte.aslab.upm.es/redmine/ files/dmsf/p_advise/161218184339_225_Lootsma_-

Fuzzy_Logic_for_Planning_and_Decision_Making.pdf.

Miguel Juan, Florez Cogollo, Cogollo-Florez Myladis, FlorezRendon Andrea, 2015. In: Measuring Quality Policy Deployment: A Fuzzy Logic Approach, Instituto Technologico Metropolitano, Medelin, Columbia. https://www.researchgate.net/profile/Juan_Cogollo-Florez

Ora Coren, 2018. In: Tiny Satellite to Play major Role in Israel's Space Ambitions, (http://www.haaretz.com/israelnews/science/.premium-1.637796)

Ramachandran Sudha, 2014

http://thediplomat.com/2014/10/indias-impressive-spaceprogram/

Scientific and Technological Cooperation, Land Remote Sensing Satellite Data, 2016. In: Memorandum of Understanding between the United States of America and India, Treaties and Other International Acts Series 16-709.

Secretariat, International cooperation in the peaceful uses of outer space: activities of Member States, 2018, A/AC.105/C.1/2018/CRP.8, Committee on the Peaceful Uses of Outer Space Scientific and Technical Subcommittee. http://www.unoosa.org/res/oosadoc/data/documents/2018/aac_1 05c_12018crp/aac_105c_12018crp_8_0_html/AC105_C1_2018 _CRP08E.pdf

Shapir Yiftah, The Launch of Israel's TecSAR Satellite - 2008 http://www.inss.org.il/index.aspx $? \mathrm{id}=4538 \&$ articleid $=1878$

Shomashekhar M, 2018. In: India-Israel Space Ties to Get a boost. (https://www.thehindubusinessline.com/news/indiaisraelspace-ties-to-get-a-boost/article9758381.ece).

Sourbes Verger I., 2016. In: EU-India Cooperation on Space and Security, (https://www.frstrategie.org/web/documents/publications/autres/2017/2017-sourbes-iai-eu-india-cooperation.pdf)

Zoe Szajnfarber, Thomas M.K Coles, Anthony C Wicht, Annalisa L Wrigel, 2014. In: Future Directions For International Space Collaborations For Exploration, IACHASL.

https://www.researchgate.net/publication/228546281_Future_di rections_for_international_space_collaboration_for_exploration 